\title{
Chemoendocrine Treatment Is Standard in Hormone Receptor-Positive Patients
}

\author{
Volkmar Müller \\ Department of Gynecology, University Breast Center, University Medical Center Hamburg Eppendorf, Germany
}

In the last decade, a relevant increase in the rate of patients cured from breast cancer has been observed. A substantial part of this improvement in treatment outcome can be attributed to more efficient chemotherapy regimens. However, the broad use of chemotherapy, even in hormonereceptor-positive patients who supposedly have a high probability of being cured with adjuvant endocrine treatment alone, raises concerns about 'over-treatment', especially in node-negative patients. These concerns are caused by the assumption that these patients do not derive any relevant additional benefit from chemotherapy. However, this view is not supported by results from trials comparing endocrine treatment with chemoendocrine therapy, which demonstrate a better outcome for chemoendocrine treatment in the overall patient cohort [1]. Although most trials lack prospective subgroup data, study results are sometimes interpreted in a way that identifies subgroups of patients (e.g. postmenopausal women) that seemingly have no benefit from additional chemotherapy. This interpretation is not supported by current meta-analyses which demonstrate that chemotherapy reduces the risk in all groups of patients, e.g. with older patients still showing significant benefit from chemotherapy [2]. This benefit is also clearly demonstrated in meta-analyses involving patients regarded as 'estrogen receptor poor', who are candidates for endocrine treatment [3]. Several just recently presented studies comparing different chemotherapy regimens showed significant improvements in efficacy also in receptor-positive patients who received endocrine treatment $[4,5]$. This demonstrates that additional benefit can be obtained by chemotherapy also in the context of current treatment regimens.

In addition, with improvements in the management of chemotherapy-associated toxicity, such as neutropenia and nausea, it is also possible to reduce side effects of chemotherapy. Currently, cardiotoxicity has gained more attention. However, this long-term side effect might be overcome with the development of highly effective non-anthracycline chemother- apy regimens. This could shift the risk-benefit ratio of adjuvant chemotherapy in favor of chemotherapy.

Nevertheless, the identification of patients who profit from chemotherapy is an important and still unsolved problem. With the development of tests that only identify those patients who have an increased risk for recurrence it will not be possible to solve the clinical problem. A test for patients with highly endocrine-responsive tumors should be able to discriminate between those that do and those that do not benefit from additional chemotherapy. Several tests reported to be able to support such treatment decisions, but mostly these tests were evaluated in retrospective analyses with treatment regimens not reflecting the current treatment standards. Also, not all studies were set up in a context that allowed to answer the questions described above [6-8]. Therefore, several ongoing clinical trials aim to verify these tests with current chemotherapy and endocrine treatment strategies in patients with nodenegative axillary status. Testing for the invasion factors uPA and PAI-1 is the mayor decision factor for chemotherapy in the European trial 'NNBC 3' [10], an RNA gene signature is applied in the European trial 'Mindact' [9] and an RNA test performed on paraffin-embedded tissue is used to guide treatment decisions in the US trial TAILORx [11]. However, all these studies are still recruiting and it will take several years until results are available. More recently, it was reported that some of these tests are capable to identify also patients with involved axillary lymph nodes that have a good prognosis with endocrine treatment alone [12]. Again, these findings need to be confirmed in prospective studies.

In conclusion, current knowledge does not allow to reliably identify a distinct group of patients with overall 'low' risk that should not be offered chemotherapy. Therefore, chemo-endocrine treatment is standard also in hormone receptor-positive patients. This is reflected by most current treatment guidelines for breast cancer patients, which do not specify subgroups of patients that should not receive chemotherapy.

\section{KARGER}

Fax +497614520714

Information@Karger.de

www.karger.com
(C) 2008 S. Karger GmbH, Freiburg

Accessible online at:

www.karger.com/brc
PD Dr. med. Volkmar Müller

Klinik und Poliklinik für Gynäkologie

Universitätsklinikum Hamburg-Eppendorf

Martinistraße 52, 20246 Hamburg, Germany

Tel. +49 40 42803-2550, Fax -4355

vmueller@uke.uni-hamburg.de 


\section{References}

1 Fisher B, Jeong JH, Bryant J, Anderson S, Dignam J, Fisher ER, Wolmark N: Treatment of lymph node-negative, oestrogen-receptor-positive breast cancer: long-term findings from National Surgical Adjuvant Breast and Bowel Project randomised clinical trials. Lancet 2004;364:858-68.

2 Peto R, for the Early Breast Cancer Trialists' Collaborative Group University of Oxford, United Kingdom: The worldwide overview: new results for systemic adjuvant therapies. Oral presentation, 30th San Antonio Breast Cancer Symposium 2007.

3 Clarke M, Coates AS, Darby SC, Davies C, Gelber RD, Godwin J, Goldhirsch A, Gray R, Peto R, Pritchard KI, Wood WC: Adjuvant chemotherapy in oestrogen-receptor-poor breast cancer: patientlevel meta-analysis of randomised trials. Lancet 2008;371:29-40

4 Nitz U, Huober JB, Lisboa B, Harbeck N, Fischer H, Moebus V, Hoffmann G, Augustin D, Weiss E, Kuhn W: Interim results of Intergroup EC-Doc Trial: A randomized multicenter phase III trial comparing adjuvant $\mathrm{CEF} / \mathrm{CMF}$ to EC-docetaxel in patients with 1-3 positive lymph nodes. J Clin Oncol 2008;26 suppl:abstr 515.
5 Jones S, Holmes F, O'Shaughnessy J, Blum J, Vukelaj S, McIntyre K, Pippen J, Bordelon J, Kirby R, Sandbach J, Hyman W, Khandelwal P, Negron A, Richards D, Mennel R, Boehm K, Meyer W, Asmar L, Muss H, Savin M: Extended follow-up and analysis by age of the US Oncology Adjuvant trial 9735: docetaxel/cyclophosphamide is associated with an overall survival benefit compared to doxorubicin/cyclophosphamide and is well-tolerated in women 65 or older. Breast Cancer Res Treat 2007; 106(suppl 1):abstr 12

6 Jänicke F, Prechtl A, Thomssen C, Harbeck N, Meisner C, Untch M, Sweep CG, Selbmann HK, Graeff H, Schmitt M: Randomized adjuvant chemotherapy trial in high-risk, lymph node-negative breast cancer patients identified by urokinasetype plasminogen activator and plasminogen activator inhibitor type 1. J Natl Cancer Inst 2001;93: 913-920.

7 Cardoso F, Van’t Veer L, Rutgers E, Loi S, Mook S, Piccart-Gebhart MJ: Clinical application of the 70-gene profile: the MINDACT trial. J Clin Oncol 2008:26:729-35.
Paik S, Shak S, Tang G, Kim C, Baker J, Cronin M, Baehner FL, Walker MG, Watson D, Park T, Hiller W, Fisher ER, Wickerham DL, Bryant J, Wolmark $\mathrm{N}$ : A multigene assay to predict recurrence of tamoxifen-treated, node-negative breast cancer. $\mathrm{N}$ Engl J Med 2004;351:2817-26.

9 www.cancer.gov/clinicaltrials/EORTC-10041.

10 www.germanbreastgroup.de/nnbc3/.

11 www.cancer.gov/clinicaltrials/digestpage/TAILORx.

12 Albain K, Barlow W, Shak S, Hortobagyi G, Livingston R, Yeh I, Ravdin P, Yoshizawa C, Baehner F, Davidson NE, Sledge G, Winer E, Hudis C, Ingle J, Perez E, Pritchard KI, Shepherd L, Allred C, Osborne K, Hayes D: Prognostic and predictive value of the 21-gene recurrence score assay in postmenopausal, node-positive, ER-positive breast cancer (S8814,INT0100). Breast Cancer Res Treat 2007;106(suppl 1):abstr 10. 